\title{
Interaction of PER2 with the Constitutive Androstane Receptor Possibly Links Circadian Rhythms to Metabolism
}

\author{
Tomaž Martini, ${ }^{1}$ Jurij Stojan, ${ }^{2}$ Damjana Rozman ${ }^{1}$ \\ and Uršula Prosenc Zmrzljak ${ }^{1, *}$ \\ ${ }^{1}$ Center for Functional Genomics and Bio-chips, Institute of Biochemistry, Faculty of Medicine, \\ University of Ljubljana, Zaloška cesta 4, Ljubljana, Slovenia \\ ${ }^{2}$ Institute of Biochemistry, Faculty of Medicine, University of Ljubljana, Vrazov trg 2, Ljubljana, Slovenia \\ * Corresponding author: E-mail: ursula.prosenc@mf.uni-lj.si \\ Tel: +38615437592 fax: +38615437588 \\ Received: 06-11-2016
}

For Cutting Edge 2017

\begin{abstract}
Period 2 (PER2) is an important factor in daily oscillations called circadian rhythms, which are emerging as one of the most important regulatory networks, responsible for homeostasis and transcriptional regulation of a number of genes. Our work shows that PER2 could act as a co-activator of the constitutive androstane receptor (CAR), a key nuclear receptor (NR) that regulates the metabolism of endobiotics and xenobiotics. Bioinformatic analysis shows that PER2 and CAR possess structural elements that could enable them to interact which was confirmed experimentally by CoIP experiment. Co-transfection of mouse hepatocarcinoma cells with plasmids overexpressing Per 2 and Car increases expression of Bmall, a potential CAR target gene, more than transfections with Car only. This is the first report indicating the interaction of PER2 and CAR.
\end{abstract}

Keywords: circadian rhythms, metabolism, period 2, constitutive androstane receptor, co-activator

\section{Introduction}

Circadian rhythms are daily oscillations in most cells and organisms. They are governed by autonomous molecular circadian oscillators that are synchronized by external cues, such as light and food. The circadian machinery is composed of positive and negative transcriptional and translational feedback loops. The major positive loop comprises of transcriptional activators BMAL1 and CLOCK that can heterodimerize and drive their own transcription as well as that of elements of the negative loop, such as Period (PER) homologues, Cryptochromes and Rev-erb $\alpha$. The transcriptional repression of Bmall due to REV-ERB $\alpha$ can be counter-balanced by ROR $\alpha$ and PPAR $\alpha{ }^{1-3}$

PER2 is involved in the negative feedback loop where it directly interacts with the transactivation complex of BMAL1-CLOCK and represses its transcriptional activation capability. It also acts in the positive loop whe- re it drives Bmall expression by acting as a co-activator of NRs, eg PPAR $\alpha .{ }^{1}$ PER2 in metabolic and mental disorders, cancer and other pathologies is currently being intensively studied. ${ }^{4-8}$ Due to its two LXXLL structural motifs, which can interact with a hydrophobic pocket of NR$\mathrm{s}$, it has been studied as a nuclear receptor co-activator. ${ }^{9}$ Perhaps one of the most important transcriptional regulator of metabolism is CAR, a NR regulator of primary and secondary metabolism. CAR can be directly or indirectly activated by various endogenous ligands, eg bilirubin, and xenobiotics, eg barbiturates. ${ }^{10-18}$ After activation and nuclear localization it interacts with co-activators and heterodimerization factors, most often the retinoid X receptor (RXR). The final protein complex can transactivate enzymes of the cytochrome P450 (CYP), glucuronosyltransferase (UGT) and multi drug resistance protein (MRP) families. ${ }^{3,13,15,19-21}$

The interaction between nuclear receptors and their co-activators is a well-documented interaction that is 
highly conserved among species. ${ }^{9,22}$ Nuclear receptors have high levels of similarity in their ligand binding domains, especially in the region of helices 3, 4 and 5. These helices form a hydrophobic cleft which interacts with leucines of the co-activators' LXXLL motifs. The two residues between the three leucines have little or no importance to binding of LXXLL motifs as they are in direct contact with the surrounding aqueous solution. Charged residues of the helices 3-5 form interactions with amino acids surrounding the LXXLL motifs which are crucial for the specificity of interactions and recognition of appropriate co-activators. The most important factor for specificity of co-activators are the two residues just before the first leucine of the LXXLL motif, usually referred as -2 and -1 . Of most interest to this study was the class 3 of LXXLL motifs, according to Savkur and Burris, which encompasses motifs SXLXXLL. ${ }^{9,23}$

Here it was shown that CAR and PER2 interact with, and activate Bmall transcription. The initial prediction was made on the basis of homology of LXXLL motifs of PER2 and several known CAR co-activators and was confirmed experimentally. Our data presents the first report of communication between drug metabolism and the circadian rhythm at the level of direct interaction between PER2 and CAR.

\section{Results}

Bioinformatic analysis of the transcription factor binding sites using MatInspector, Matrix Library 9.4 and User-defined IUPAC strings revealed potential binding sites for CAR on the Bmall promoter, eg for CAR/RXR at 414-438 (positive strand) of GXP_5050588 (Bmall Mus musculus). ${ }^{24-26}$ This provided a sufficient basis for the transfection experiments that showed induced expression of a Bmall luc reporter when Hepa 1-6 cells were transfected with $\operatorname{Car}(\mathrm{P}<0.01)$. The induction was further enhanced when co-transfection with $\mathrm{Car}$ and Per2 was performed $(\mathrm{P}<0.01)$ which suggests an either direct or indirect influence of PER2 on CAR transactivation of Bmall (Figure 1). Surprisingly, the transactivation of Bmall with vectors overexpressing CAR and PER2 was not significantly different than transactivation with positive control overexpressing PPAR $\alpha$ and PER2 (Figure 1) that co-immunoprecipitate at Bmall regulatory sites. ${ }^{1}$ The lack of a statistically significant difference might suggest a similar mechanism of transactivation which may lead to the exploration of structural properties of both PER2 and CAR to evaluate if a direct interaction between the proteins is plausible.

Bioinformatic analysis showed that $\mathrm{PGC1} \alpha$ (PPAR $\gamma \mathrm{C} 1 \mathrm{~A})$, a known CAR and PPAR $\gamma$ co-activator, may interact with CAR via its motif SLLKKLL (Mus musculus), which is homologous to both SXLXXLL motifs of PER2 (Figure 2), namely SGLLNLL (Mus muscu-

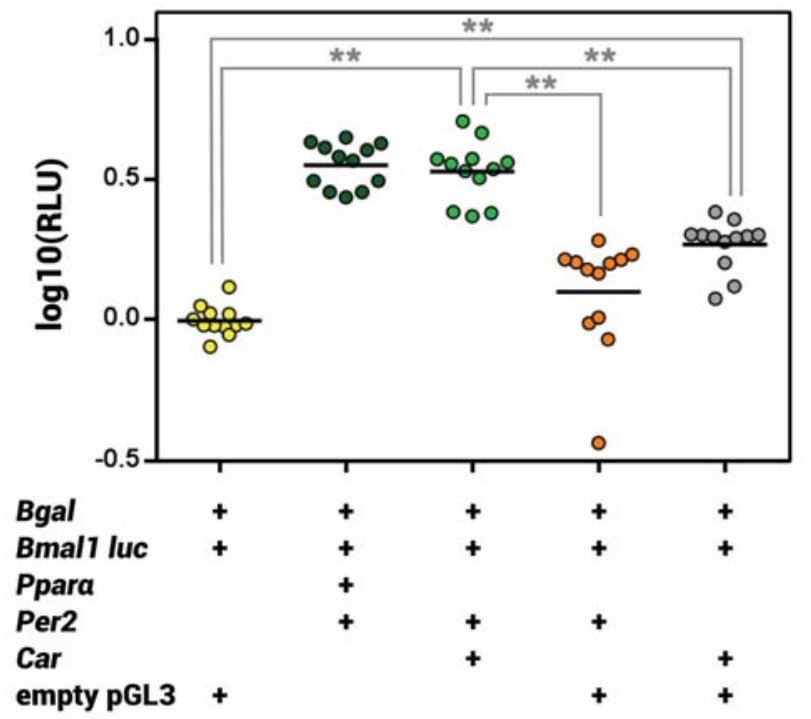

Figure 1. Co-transfection of Hepa 1-6 cells with CAR and PER2 overexpression plasmids induces promoter activity of Bmall luc reporter. This induction is similar to the one observed when performing co-transfections with Ppar $\alpha$ and Per2 $(\mathrm{P}<$ $0.0001)$ and different to the one observed when performing transfections with Car only $(\mathrm{P}<0.0001)$. The $\log 10$ relative luciferase units of individual wells for the specific transfection mix are shown. $* *-\mathrm{P}<0.01$

lus) and SDLLNLL (Mus musculus). ${ }^{27-29} \mathrm{~A}$ further co-activator of CAR and PPAR $\gamma$ PGC1 $\beta$, which has three LXXLL motifs, all with a serine at a 1 or -2 position, also exists. A similar arrangement with a serine residue in front of a LXXLL motif can also be observed in NCoA6, another CAR co-activator. ${ }^{28,30}$

As both PER2 and PGC1 $\alpha$ are co-activators of PPAR $\gamma$, a NR involved in lipid and carbohydrate metabolism, attention was focused on the homology of the nuclear receptor. Most receptor residues that are in contact with LXXLL motifs have no charge pointing towards the co-activator motifs, besides two very distinct lysins at both the CAR and PPAR $\gamma$ at homologous positions. The receptors also seem to have high 3D similarity of the hydrophobic cleft as helices $3,4,5$ are positioned in a similar manner. Both receptors seem to bind LXXLL motifs at the »end of helix 5 « to the »end of helix $3 \ll$, which coincides with the lysine positioning. ${ }^{31-35}$ Even though this could be projected onto many nuclear receptors, the position of the lysine at helix 5 could additionally explain the favouring of co-activators with a serine before LXXLL. ${ }^{9,29,36}$

The hypothesis that PER2 and CAR interact directly was confirmed with co-immunoprecipitation (Figure 3). For this, Car-Flag and Per2-V5 co-transfection was performed. Initial release of proteins from Sepharose beads was performed at $70{ }^{\circ} \mathrm{C}$ and revealed the V5 reactive protein at an approximate size of $40 \mathrm{kDa}$. After additional heating of Sepharose at $95{ }^{\circ} \mathrm{C}$ for $2 \mathrm{~min}$, a 135 


\begin{tabular}{|c|c|}
\hline hPER 2/1st & 015055 \\
\hline hPER2/2nd & 015055 \\
\hline $\mathrm{hPGC} 1 \alpha / 2 \mathrm{nd}$ & Q9UBK2 \\
\hline $\mathrm{hPGC} 1 \mathrm{a} / 3 \mathrm{rd}$ & JBK2 \\
\hline hPGC1 $1 \beta / 1$ st & 5YN6 \\
\hline hPGC1 $1 \beta / 2$ nd & 6YN6 \\
\hline hNCoA6/1st & Q14686 \\
\hline $\mathrm{hNCOA6} / 2 \mathrm{nd}$ & Q14686 \\
\hline mPER2/1st & 054943 \\
\hline mPER2/2nd & 054943 \\
\hline $\mathrm{PGC} 1 \alpha / 2 \mathrm{nd}$ & 070343 \\
\hline $\mathrm{PGC} 1 \alpha / 3 \mathrm{rd}$ & 070343 \\
\hline${ }_{\mathrm{nPGC}} 1 \beta / 1 \mathrm{st}$ & Q8VHJ \\
\hline $\mathrm{mPGC} 1 \beta / 2 \mathrm{nd}$ & Q8VHJ7 \\
\hline $\mathrm{nPGC} 1 \beta / 3 \mathrm{rd}$ & Q8VHJ7 \\
\hline $\mathrm{mNC}$ (A6/1st & Q9JL19 \\
\hline $\mathrm{mNCOA6} / 2 \mathrm{n}$ & Q9JL1 \\
\hline
\end{tabular}

KSHENEIRYHPFRMTPYLVKVRDQQGAESQLCCLLLAERVHSGYEAPRIPPEKRI TSRDQQPKAPLTRDEPSDTQNSDALSTSSGLLNLLLNEDLCSASGSAASESLGSG DGDVTTDNEASPSSMPDGTPPPQEAEEPSLLKKLLLAPANTQLSYNECSGLSTQN PAIVKTENSWSNKAKSICQQQKPQRRPCSELLKYLTTNDDPPHTKPTENRNSSRD SASPAPSSAPPSPAPEKPSAPAPEVDELSLLQKLLLATSYPTSSSDTQKEGTAWR PKACSNPSQQVRSRPWSRHHSKASWAEFSILRELLAQDVLCDVSKPYRLATPVYA PFSGAPNGNQMSCGQNPGFPVNKDVTLTSPLLVNLLQSDISAGHFGVNNKQNNTN DGQPSDPNKLPSVEENKNLVSPAMREAPTSLSQLLDNSGAPNVTIKPPGLTDLEV KHHENEIRYQPFRMTPYLVKVQEQQGAESQLCCLLLAERVHSGYEAPRIPPEKRI TSRDRQPKAPPTCNEPSDTQNSDAISTSSDLLNLLLGEDLCSATGSALSRSGASA DGAVTTDNEASPSSMPDGTPPPQEAEEPSLLKKLLLAPANTQLSYNECSGLSTQN PAIVKTENSWSNKAKSICQQQKPQRRPCSELLKYLTTNDDPPHTKPTENRNSSRD GLAAFPELDEGDTPSCTPASPAPLSAPPSPTLERLLSPASDVDELSLLQKLLLAT PASPAPLSAPPSPTLERLLSPASDVDELSLLQKLLLATSSPTASSDALKDGATWS PIPQACSSLSRQVQPRSRHPPKAFWTEFSILRELLAQDILCDVSKPYRLAIPVYA PFGGAPNGSQMSCGQNPGFPVNKDVTLTSPLLVNLLQSDISAGHFGVNNKQNNTN DGQPLDPNKLPSVEENKNLMSPAMREAPTSLSQLLDNSGAPNVTIKPPGLTDLEV

Figure 2. Alignment showing similarity between PER2 and known co-activator LXXLL motifs of CAR, namely PGC1alpha, NCoA6 and PGC1beta. ${ }^{28,30}$ The letters $\mathrm{h}$ and $\mathrm{m}$ before the protein name designate species Homo sapiens and Mus musculus, with the sequential number of the noted LXXLL and UniProt/Swiss-Prot entry number following the protein name. The predicted LXXLL motifs with residues marked as 1-5 are shown in red, as are serines located just before LXXLL. Of note is a negatively charged side-chain, or a hydroxyl group containing residues (E, S, T) just in front of the -2 serine..$^{29}$

a)

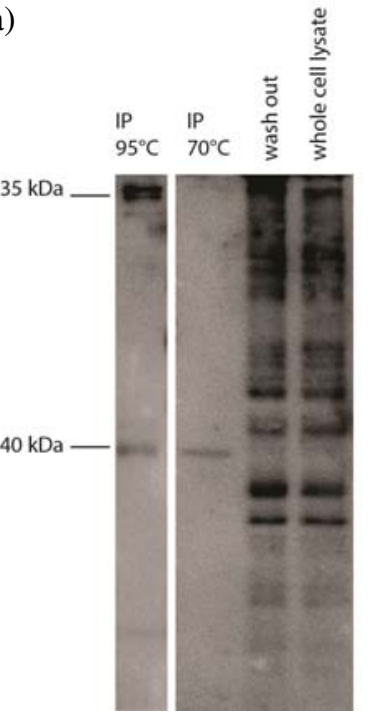

b)

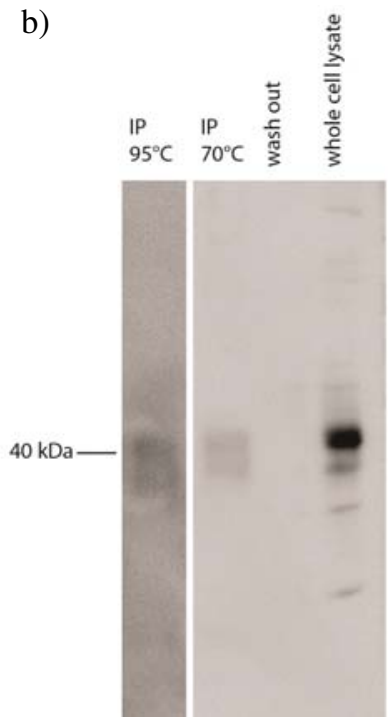

Figure 3. Co-immunoprecipitation with FLAG Ab conjugated Sepharose of Car-Flag and Per2-V5. A: Western blot with V5 Ab - PER2 shows two bands, at 40 and $135 \mathrm{kDa}$. After the final incubation of Sepharose beads at $70{ }^{\circ} \mathrm{C}$, only the $40 \mathrm{kDa}$ form was visible on the blot. The $135 \mathrm{kDa}$ isoform was visible after additional incubation at $95{ }^{\circ} \mathrm{C}$. B: Western blot with FLAG Ab - the signal of CAR is in the range of expected protein size $(40 \mathrm{kDa})$.

$\mathrm{kDa}$ protein was released (Figure 3A), corresponding to the expected size of PER2. ${ }^{29}$ The FLAG reactive protein was detected very faintly, irrespective of temperature, at $40 \mathrm{kDa}$ (Figure 3B). This could correspond to CAR. ${ }^{29}$ This corroborates the prediction that the two proteins could interact in a co-activator and nuclear receptor manner.

\section{Materials and Methods}

\section{1. Plasmids}

Bmall luc, having a Bmall promoter cloned into a pGL3 luciferase reporter vector, Per2, coding for a V5tagged PER2, and Ppar $\alpha$ constructs were kindly provided by J. Ripperger and U. Albrecht (Department of Biology, Faculty of Science, University of Fribourg, Switzerland) and have been previously described in more detail. ${ }^{1}$

The Car expression construct was kindly provided by JeanMarc Pascussi (Institut de genomique fonctionnelle, Montpellier, France) and it was constructed by Negishi Masahiko (NIH, North Carolina, USA) and has previously been described in more detail. ${ }^{37}$

The Car-Flag plasmid was kindly provided by Negishi Masahiko (NIH, North Carolina, USA) and has previously been described in more detail. ${ }^{38}$

An empty pGL3 basic vector (Promega) was used to perform transfections with equal ammounts of DNA. All wells were transfected with $50 \mathrm{ng}$ Bgal - pSV- $\beta$-Galactosidase Control Vector (Promega), for normalization. All constructs besides the commercial pGl3 basic and Bgal represent Mus musculus.

\section{2. Transfections}

Transfections were performed on Hepa 1-6 cells available from the European Collection of Authenticated Cell Cultures. The cells were held at $5 \% \mathrm{CO} 2$ and $37{ }^{\circ} \mathrm{C}$ and transfered to 96 -well microplates 24 hours prior to transfections with $5 \times 10^{6}$ cells in DMEM and $10 \%$ FBS. For transfections X-tremeGENE HP DNA (Roche) was 
used according to manufacturer's instructions. Total plasmid mass was equal to $200 \mathrm{ng}$ per well, with each construct of interest at $50 \mathrm{ng}$ and total mass added to $200 \mathrm{ng}$ with the pGL3 basic vector. The negative control represents transfections with Bgal, Bmall luc and pGL3 basic vector, a positive control of Bgal, Bmall luc, Ppar $\alpha$ and Per2 was used.

\section{3. Luciferase assay and statistical analysis of results}

Cells were lysed using Passive Lysis Buffer (Promega). Luciferase assay was performed using the ONE-Glo Luciferase (Promega) according to manufacturer's instructions and measurements were performed on Synergy H4 (BioTek). Results were normalized using analysis of $\beta$-galactosidase activity and additional normalization to positive control using luciferase activity was performed for microplate comparisson. Analysis of variance was performed and results were logarithmized to achieve variance homogeneity. The t-test analysis was performed with GraphPad Prism 6.0 software. In cases where significance is very high, the software returns $\mathrm{p}$ values in the form $\mathrm{p}>0.0001$.

\section{4. Co-immunoprecipitation (Co-IP)}

HeLa cells were seeded on 6-well plates and cotransfected with Car-Flag and V5-tagged Per2 using Lipofectamine 2000 (Thermo Fisher Scientific). Cells were harvested 2 days after transfection using 200 microliters of the lysis buffer: $50 \mathrm{mM}$ Tris - $\mathrm{HCl}$ at $\mathrm{pH} 7.5,150 \mathrm{mM} \mathrm{Na}-$ $\mathrm{Cl}, 0,5 \%(\mathrm{w} / \mathrm{v}) \mathrm{NP}-40$ and complemented with protease inhibitors (Roche). The cell lysate was agitated for $10 \mathrm{~min}$ at $4{ }^{\circ} \mathrm{C}$ and centrifuged at $14000 \mathrm{~g} 20 \mathrm{~min}$ at $4{ }^{\circ} \mathrm{C}$. Supernatant was transferred to a tube containing FLAG-coupled Sepharose beads (Sigma-Aldrich) and rotated for $2 \mathrm{~h}$ at 4 ${ }^{\circ} \mathrm{C}$. After the centrifugation at $10000 \mathrm{~g}$ for $5 \mathrm{~min}$ at $4{ }^{\circ} \mathrm{C}$ the supernatant was then collected and stored as a whole cell lysate sample. Sepharose was washed 3 times with additional 200 microliters of lysis buffer and the first washout was collected as wash out sample. 50 microliters of Laemmli buffer was added to the Sepharose, followed by heating for $10 \mathrm{~min}$ at $70{ }^{\circ} \mathrm{C}$ and again for $2 \mathrm{~min}$ at $95^{\circ} \mathrm{C}$. Western blot was perfomed with 3 different samples: whole cell lysate, wash out and immunoprecipitate (IP) in two parallel conditions, one with anti-FLAG Ab A8592 (Sigma-Aldrich) and the other with anti-V5 Ab V8137 (SigmaAldrich).

\section{5. Discussion}

The comparable transactivation of Bmall following co-transfections with Car/Per2, or Pparo/Per2 may suggest a similar mechanism of transcriptional activation of Bmall. If this is the case then, in conjucntion with ChIP experiments revealing binding of PER2 and PPAR $\alpha$ at regulatory regions of Bmall, ${ }^{1}$ this could further support the proposal that PER2 could potentially act as CAR's co-activator and that the pair can form transactivation complexes either alone or with other partners. This is further supported by finding CAR binding sites at the Bmall promotor. The discovery is interesting as both proteins are important for cell homeostasis. However, PER2 is not the only co-activator of these nuclear receptors and PER2 is expressed at certain times of the day. To confidently state how important is the effect of different Bmall transcriptional activity, this should be tested on reporter cell lines. We can speculate that additive effects of xenobiotic ingestion, social jet lag and nutrition overload can affect circadian clock driven endogenous liver metabolism. This can result in liver abnormalities, such as non-alcoholic fatty liver disease that could terminate in HCC.

Since some of the predictions of this study were based on homology, it is worth noting that according to Savkur and Burris the amino acid at -1 of their class 3 LXXLL motifs should be an non-polar amino acid. ${ }^{9}$ However, since human and mouse 2nd PER2 LXXLL have G or $\mathrm{D}$ at -1 , with high conservation of the rest of the sequence, motifs that do not follow this strict consensus of an unpolar -1 residue are shown in our alignment. ${ }^{29}$ As well as this, the residue at -1 most probably points outwards from the hydrophobic pocket and therefore does not directly interact with helices 3-5 of NRs. ${ }^{39}$ It would be worth exploring if it could interact with the charge clamp of NRs. ${ }^{9,31,40-42}$

Another interesting observation is the presence of a band at approximately $40 \mathrm{kDa}$ at the western blot with anti-V5 Ab. Similar sized bands have been observed in our previous work, where a $>40 \mathrm{kDa}$ band was detected with western blot from mouse liver samples, with the use of a different Ab (Abcam ab467). Unfortuantely this could not be verfified using our CoIP samples with these $\mathrm{Ab}$, as $\mathrm{Ab}$ cam does not provide this specific Ab any more. Work from other researchers has shown the existence of a shorter PER2S isoform in Homo sapiens with the size of $45 \mathrm{k}$ $\mathrm{Da}$ and co-IP at $55 \mathrm{kDa}^{43}$ If a similar truncated form of PER2 was observed, it could be speculated that PER2 can interact with CAR with its first LXXLL. However, this does not exclude an interaction of PER2 with CAR with its second LXXLL. ${ }^{1}$ It may be possible that a co-activator interacts with an NR with multiple LXXLL motifs, but with a different affinity. Although a cocktail of protease inhibitors were used with the lysis buffer, it is still possible that the $>40 \mathrm{kDa}$ band is a product of protein degradation.

It is interesting to note that $\mathrm{Car}$ shows both diurnal expression patterns in liver, with Car mRNA levels oscillating in phase with Bmall, and the possibility to be activated by ligands. The induction could very well be dependent on the phase or time of induction. ${ }^{44,45}$ If this is the case, such findings should be considered in the pharmacoki- 
netics of drug active ingredients, especially as CAR regulates the expression of several CYPs. ${ }^{18,21,46}$ This work may therefore provide an important new link in understanding the connection between internal clock machinery, metabolism and pharmacokinetics.

As CAR can be activated by xenobiotics, such as flavonoids, cathehins and similar poliphenols, and also active ingredients of drugs, eg. barbiturates, paracetamol and some compounds with a steroid-like structure, it would also be interesting to see if such activation has any physiological effect on transcription of genes involved in circadian rhythms. ${ }^{13,16,19,46}$ It would be possible that high levels of CAR could affect the molecular clock in the periphery, but CAR also binds other co-activators. We cannot exclude that the robust molecular clock could be affected, which would mean that different CAR activators (eg. xenobiotics) could have an effect on liver circadian regulation of various metabolic pathways.

This work also suggests that period homologues should be considered as possible NR co-activators, not only of NRs that have an established role in circadian rhythms. Perhaps such mechanisms of multiple co-activators being able to activate a single NR could provide a compensatory mechanism in case of co-activator deregulation. On the other hand, different co-activators are expressed differentially in tissues with different phases of expression, which could in fact define a NR's tissue and time specific function.

In conclusion, we show that CAR and PER2 can form an interaction which has implicaitons for circadian aspects of drug metabolism.

\section{6. Authors' contributions}

T. M. performed transfections, the luciferase assay and bioinformatical and structural analyses. The bioinformatical and structural analyses were performed under expert supervission and guidance of J.S.. U.P.Z. first noticed the possibility of an interaction between CAR and PER2 during her preliminary screenings for interactions of PER2 with nuclear receptors. She also performed co-IP. Experiment planing and protocol preparation was performed by U.P.Z. and D. R. The manuscript draft was prepared by T. M. and finalised by all authors. All authors read and approved the final manuscript.

\section{7. Acknowledgements}

We would kindly like to thank J. Ripperger and U. Albrecht for providing Bmall luc, Per2 and Ppara constructs, JM. Pascussi for the Car expression construct and M. Nagishi for the Car-Flag. The view of J. Ačimovič on statistical analysis of transfection results is highly appreciated. A sincere thank you to $\mathrm{M}$. Hafner, $\mathrm{Ni}$. and $\mathrm{Nu}$. Trošt and Ž. Urlep for their advice. We would also like to thank I. Mlinarič Raščan for a critical overview. The work described here contains part of the master thesis work of T. M. and was supported by the Slovenian Research Agency program grants P1-0104 and P1-0390.

\section{References}

1. I. Schmutz et al., Genes Dev. 2010, 24 (4), 345-357. https://doi.org/10.1101/gad.564110

2. R. Chavan et al., Nat. Commun. 2016, 7.

3. U. P. Zmrzljak, D. Rozman, Chem. Res. Toxicol. 2012, 25 (4), 811-824. https://doi.org/10.1021/tx200538r

4. M. Zeman et al., Mol. Med. Rep. 2008, 1 (4), 599-603.

5. T. Okabe et al., PLoS ONE 2014, 9 (10), e109693. https://doi.org/10.1371/journal.pone.0109693

6. S.-T. Chen et al., .

7. B. Grimaldi et al., Cell Metab. 2010, 12 (5), 509-520. https://doi.org/10.1016/j.cmet.2010.10.005

8. G. Hampp et al., Curr. Biol. 2008, 18, 678-683. https://doi.org/10.1016/j.cub.2008.04.012

9. R. S. Savkur, T. P. Burris, J. Pept. Res. Off. J. Am. Pept. Soc. 2004, 63 (3), 207-212. https://doi.org/10.1111/j.1399-3011.2004.00126.x

10. M. Hafner et al., Curr. Drug Metab. 2011, 12 (2), 173-185. https://doi.org/10.2174/138920011795016890

11. W. Huang et al., Proc. Natl. Acad. Sci. U. S. A. 2003, 100 (7), 4156-4161.

https://doi.org/10.1073/pnas.0630614100

12. H. R. Kast et al., J. Biol. Chem. 2002, 277 (4), 2908-2915. https://doi.org/10.1074/jbc.M109326200

13. T. Kawamoto et al., Mol. Cell. Biol. 1999, 19 (9), 63186322. https://doi.org/10.1128/MCB.19.9.6318

14. K. Kobayashi et al., Arch. Toxicol. 2015, 89 (7), 1045-1055. https://doi.org/10.1007/s00204-015-1522-9

15. J. M. Maglich et al., J. Biol. Chem. 2004, 279 (19), 1983219838. https://doi.org/10.1074/jbc.M313601200

16. J.-M. Pascussi et al., Mol Pharmacol 2000, 58 (6), 14411450 .

17. T. Rezen, Expert Opin. Drug Metab. Toxicol. 2011, 7 (4), 387-398. https://doi.org/10.1517/17425255.2011.558083

18. J. Zhang et al., Science 2002, 298 (5592), 422-424. https://doi.org/10.1126/science.1073502

19. R. Yao et al., J. Agric. Food Chem. 2010, 58 (4), 2168-2173. https://doi.org/10.1021/jf903711q

20. H. Yang, H. Wang, Protein Cell 2014, 5 (2), 113-123. https://doi.org/10.1007/s13238-013-0013-0

21. K. Monostory, Z. Dvorak, Curr. Drug Metab. 2011, 12 (2), 154-172. https://doi.org/10.2174/138920011795016854

22. A. Brenna et al., Mol. Biol. Cell 2012, 23 (19), 3863-3872. https://doi.org/10.1091/mbc.E12-02-0142

23. K. Suino et al., Mol. Cell 2004, 16 (6), 893-905.

24. K. Cartharius et al., Bioinformatics 2005, 21 (13), 29332942. https://doi.org/10.1093/bioinformatics/bti473

25. C. Frank et al., J. Biol. Chem. 2003, 278 (44), 43299-43310. https://doi.org/10.1074/jbc.M305186200 
26. K. A. Arnold et al., Nucl. Recept. 2004, 2 (1), 1. https://doi.org/10.1186/1478-1336-2-1

27. G. B. Rha et al., J. Biol. Chem. 2009, 284 (50), 3516535176. https://doi.org/10.1074/jbc.M109.052506

28. T. Shiraki et al., J. Biol. Chem. 2003, 278 (13), 1134411350. https://doi.org/10.1074/jbc.M212859200

29. A. Bateman et al., Nucleic Acids Res. 2015, 43 (D1), D204D212. https://doi.org/10.1093/nar/gku989

30. S. Surapureddi et al., Mol. Pharmacol. 2008, 74 (3), 913923. https://doi.org/10.1124/mol.108.048983

31. K. Suino et al., Mol. Cell 2004, 16 (6), 893-905.

32. K. Wakabayashi et al., Biol. Pharm. Bull. 2011, 34 (7), 1094-1104. https://doi.org/10.1248/bpb.34.1094

33. Y. Li et al., J. Biol. Chem. 2008, 283 (27), 19132-19139. https://doi.org/10.1074/jbc.M802040200

34. L. Shan et al., Mol. Cell 2004, 16 (6), 907-917.

35. S. Hennig et al., PLoS Biol. 2009, 7 (4), e94. https://doi.org/10.1371/journal.pbio.1000094

36. H. M. Berman et al., Nucleic Acids Res. 2000, 28 (1), 235 242. https://doi.org/10.1093/nar/28.1.235

37. P. Honkakoski et al., Mol. Cell. Biol. 1998, 18 (10), 56525658. https://doi.org/10.1128/MCB.18.10.5652

38. Y. E. Timsit, M. Negishi, PLoS ONE 2014, 9 (5). https://doi.org/10.1371/journal.pone.0096092

39. R. A. Sayle, E. J. Milner-White, Trends Biochem. Sci. 1995, 20 (9), 374. https://doi.org/10.1016/S0968-0004(00)89080-5

40. M. V. Milburn et al., Nature 1998, 395 (6698), 137-143. https://doi.org/10.1038/25931

41. C. y Chang et al., Mol. Cell. Biol. 1999, 19 (12), 8226-8239. https://doi.org/10.1128/MCB.19.12.8226

42. I. Dussault et al., Mol. Cell. Biol. 2002, 22 (15), 5270-5280. https://doi.org/10.1128/MCB.22.15.5270-5280.2002

43. D. Avitabile et al., Cell. Mol. Life Sci. 2014, 71 (13), 25472559. https://doi.org/10.1007/s00018-013-1503-1

44. Y. Kanno et al., Nucl. Recept. 2004, 2 (1), 6. https://doi.org/10.1186/1478-1336-2-6

45. X. Yang et al., Cell 2006, 126 (4), 801-810. https://doi.org/10.1016/j.cell.2006.06.050

46. L. M. Slosky et al., Mol. Pharmacol. 2013, 84 (5), 774-786. https://doi.org/10.1124/mol.113.086298

47. R. A. Sayle, E. J. Milner-White, Trends Biochem. Sci. 1995, 20 (9), 374. https://doi.org/10.1016/S0968-0004(00)89080-5

48. V. Ritchie, D. W., Venkatraman, 2010.

49. P. M. C. Guex, N., Electrophoresis 1997, 18, 2714-2723. https://doi.org/10.1002/elps.1150181505

50. M. Tarini et al., IEEE Trans. Vis. Comput. Graph. 2006, 12 (5). https://doi.org/10.1109/TVCG.2006.115

\section{Povzetek}

Period 2 (PER2) je pomemben faktor pri dnevnih oscilacijah, imenovanih cirkadiani ritmi. Ti so eni najpomembnejših regulatornih zank, ki so pomembne za uravnavanje homeostaze in uravnavanja prepisa velikega števila genov. Dokazali smo, da lahko PER2 deluje kot ko-aktivator konstitutivnega androstanskega receptorja (CAR), ključnega jedrnega receptorja pri uravnavanju metabolizma endobiotikov in ksenobiotikov. Bioinformatska analiza je pokazala, da PER2 in CAR vsebujeta strukturne elemente, ki omogočajo njuno interakcijo. To je bilo eksperimentalno potrjeno s CoIP poskusom. KO-transfekcija mišjih hepatokarcinomskih celic s plazmidi, ki omogočajo povečano izražanje Per2 in Car, poveča izražanje Bmall, potencialni tarčni gen CAR. Povečano izražanje Bmall v celicah je višje, kot če so tranficirane le s Car plazmidom. To je prvo poročilo o interakciji PER2 in CAR. 